\title{
REMEMBERING A CONVULSIVE WAR: WHITMAN'S MEMORANDA DURING THE WAR AND THE THERAPEUTICS OF DISPLAY
}

\author{
MARK B. FELdMAN
}

WhILE THE CENTRALITY of the Civil War to Whitman's life and poetry has been quite thoroughly noted, ${ }^{1}$ less well accounted for are his prose writings about the war and his statements that the war resists representation. Whitman's diaristic writings about the war, published in Memoranda During the War (1875) and included almost without change in Specimen Days (1882), were very different from his more optimistic Civil War poetry: Drum-Taps (1865) and Sequel to Drum-Taps (1865-1866). ${ }^{2}$ The prose writings draw on Whitman's experiences as an unaffiliated volunteer nurse at hospitals in Washington D.C. and Virginia between 1862 and $1865 .{ }^{3}$ In Memoranda During the War, Whitman declared that "the real war will never get in the books," although he felt that the war, especially "the hospital part of the drama from ' 61 to ' 65 , deserves indeed to be recorded," and that this was the "marrow" of the entire conflict. Whitman urged his readers to "think how much, and of importance, will be-how much civic and military, has already been-buried in the grave, in eternal darkness." Writing about the war during the Gilded Age, he also warns that, "In the mushy influences of current times, too, the fervid atmosphere and typical events of those years are in danger of being totally forgotten" ( $P W, 1: 116-117)$. Rather than burying and forgetting the war, Whitman calls for its illumination, display, and memorialization. ${ }^{4}$

In Memoranda, in a note entitled "Convulsiveness," placed just after his declaration that the real history of the war will never be written and that the hospital scenes must be chronicled (and later, in Specimen Days, moved just before the final section), Whitman wrote that "The war itself, with the temper of society preceding it, can indeed be best described by that very word convulsiveness" (PW, 1:112). Convulsions are unwilled muscle contractions that produce spasms or seizures; the word is commonly used in an extended, metaphorical sense to connote political and social unrest. Less apparent, however, is the fact that the word itself contains contradictory and divisive ideas. The prefix conmeans together, while the Latin verb vellare means to pull or tear. ${ }^{5}$ For 
Whitman the war had this contradictory double valence of pulling the nation apart and bringing it together into a more lasting union based on adhesiveness.

Although representing civil war as convulsive was a commonplacefor instance, Herman Melville in the "Supplement" to Battle-Pieces (1866) described the war as a "great civil convulsion"-Whitman's thematization of the war's convulsiveness was more thoroughgoing and complex. ${ }^{6}$ The war of disunion and the subsequent dismembering of bodies, I will argue here, convulsed and stalled Whitman's poetics, which depended upon a series of metaphoric relations between body, nation, and text. Whitman shows us how the Civil War, a convulsion of the nation, produced wounded bodies that often convulsed in pain and twitched like broken machinery. These bodies could no longer perform the metaphoric work that Whitman demanded of them in his earlier exuberant poetry of the pre-Civil War editions of Leaves of Grass. The most emblematic example of bodies that could no longer function metaphorically was provided by the wounded soldiers-whom he terms "specimens" and "cases"-in the makeshift hospital that previously housed the Patent Office Museum. This setting, along with Whitman's particular representational strategies, suggests an equivalence between the wounded soldiers and the patented machinery exhibited in the museum's display cases. These wounded bodies, bearing the deforming and de-individualizing signature of technology, are incapable of functioning as displays of a working democracy.

Despite and indeed through these gruesome narrative displays, Whitman struggled to find a way to represent the war therapeutically. Memoranda bears witness to his search for an appropriate representational mode through which to remember the war and prevent its aestheticization, its romanticization, or its display as freakish spectacle. In other words, Whitman searched for a representational form that would preserve the convulsiveness of the period.

In what follows, I first contextualize the representational challenges posed by the Civil War by considering some of the underpinnings of Whitman's pre-Civil War poetics. Then I discuss how in Drum-Taps and Sequel to Drum-Taps Whitman managed to remain generally optimistic about the war and the possibility of representing it. The remaining sections of the essay treat various aspects of Whitman's prose writings about the war. Not only are these texts less discussed and critically neglected, but most critics who write about Whitman's wartime prose see it as consistent with or even as the culmination of his more optimistic pre-war poetry. In contrast I see these prose writings as the moment when important features of Whitman's pre-war poetics became untenable. Finally, in analyzing Whitman's search for a literary form in which 
to represent the war I consider other ways in which the war was remembered and memorialized.

\section{The Convulsing of Whitman's Democratic National Poetics}

From the earliest editions of Leaves of Grass, Whitman positioned himself as a democratic, national poet who could fulfill Emerson's call in his 1843 essay, "The Poet," for a writer who would represent America. In the preface to the 1855 edition of Leaves of Grass, Whitman noted that "The United States themselves are essentially the greatest poem" ( $L G, 709)$, and his ambition, of course, was to give voice to this poem. Whitman's project of national poetic representation relied upon the solidity and adhesiveness of the union and the fluid and continuous circulation of a series of metaphorical equivalences between body, nation, and text.

The underpinnings of Whitman's poetics were thrown into disarray by the war and the fact that the wounded body was no longer able to do the metaphoric work that it could in Leaves of Grass (1860), especially in "Walt Whitman," which later became "Song of Myself," and the "Calamus" poems. My brief reading of Whitman's pre-war poetics focuses on the 1860 edition of Leaves of Grass because it was the first to include the "Calamus" cluster and the last edition before the war. Whitman's poetics depended upon the interchangeability of body and text; as Timothy Sweet in Traces of War notes, "an insistence on the body as text and text as a body' is often considered to be the motivating force of Whitman's poetics." Similarly, Whitman continually linked the individual body with the body politic or the nation. In "Walt Whitman," Whitman wrote that he is "Walt Whitman, an American, one of the roughs, a kosmos," and later he noted, "I am large-I contain multitudes" (LG Var., 1:82). In both these instances, the individual body is complicated and contradictory, containing irreconcilable multitudes, like a democratic nation. This metaphor works the other way, as the nation is also imagined as a body. In Democratic Vistas, Whitman wrote about the Civil War in a way that links the nation and the body: "the wound, the amputation, the shattr'd face or limb, the slow hot fever ... all the forms of maiming, operation, and disease ... Alas! America have we seen, though only in her early youth, already to hospital brought" (PW, 2:378).

Whitman's pre-war poetics also relied upon a circular vision in which death is recovered as a moment of pastoral rebirth. For instance, in "Walt Whitman" death gives birth to grass: "the beautiful uncut hair of graves" that "transpire from the breasts of young men." In addition to these beautiful and sensual images, Whitman declares optimistically that 
"The smallest sprout shows there is really no death" (LG Var., 1:7). Towards the end of the poem when Whitman is imagining his own death and how his poetry will outlive him, he is able to see in death "form, union, plan" (LG Var., 1:81). This optimism and ability to see purpose in death was shaken by Whitman's experiences of the war.

I have argued, very hastily, that central to Whitman's democratic poetics are a series of metaphorical equivalences and that his poetics depends on the fluid circulation of these linked states and concepts. For instance, the body is a text and the nation is a body. These can also be reversed: the text is a body and the body is a nation. Whitman's poetics, what I term his poetic machinery, depends upon the continual reversibility of these metaphors and their continual circulation. I use the term "poetic machinery" metaphorically, as does Whitman when he compares poetry to industry and technology. Although Whitman repeatedly described poesis in industrial, technological, and machinic terms, these are merely evocative metaphors. The Civil War conclusively demonstrated their metaphoric status by rendering them literal, material, and therefore inoperable as metaphors.

The Civil War posed a series of grave challenges to Whitman's poetics and threatened to stall his poetic machinery, to arrest the fluid and continuous circulation of metaphorical equivalences outlined above. Most simply, the war horribly deformed countless bodies; this, in turn, de-formed and unsettled the poetic forms and formulas that Whitman had relied on. The war made the interchangeability of body and text, and the metaphoric equivalence of individual body and nation, problematic. While some hoped that a new and stronger union could be forged out of the crucible of war, wounding and bodily chaos made the metaphorical equivalences between body and nation, and body and text, laid out above, untenable and unpalatable. The wounded and broken bodies threatened to remain so particular as to make any metaphoric exchange or work impossible. These bodies concretized, literalized, and made grotesque the metaphoric equivalences outlined above. This sudden ubiquity of actual wounded bodies nullified much of the body's metaphoric potential of which Whitman's earlier poetry took such spectacular advantage.

After this brief discussion of Whitman's poetic machinery, we are better prepared to understand what he meant when he declared that "The war itself . . . can indeed be best described by that very word itself convulsiveness" and that Memoranda was a "batch of convulsively written reminiscences" (PW, 1:112)..$^{9}$ When a body convulses, violent and repetitive involuntary muscle contractions produce contortions of the body or limbs. M. Wynn Thomas suggests that Whitman's use of the term convulsiveness shows "how his society had been electro-spiritually galvanized into action," 10 and Mark Maslan suggests that the word is 
associated both with orgasmic shudders and inspired automatism. ${ }^{11}$ Despite these optimistic glosses, the main associations of the term within Whitman's prose writings are negative. The war's convulsiveness caused the breakdown of the metaphoric exchanges that undergirded what I have termed Whitman's poetic machinery. These bodies could no longer do the metaphoric work that the body was called on to do in the 1860 edition of Leaves of Grass. Even Whitman's own body was driven to convulsions, to seizures and temporary paralysis, in 1863,1865, and 1873. ${ }^{12}$ Whitman's memories of the war were also convulsive: they were unwilled and seem to exactly repeat the original experience. Whitman writes about how he, as well as the soldiers, suffered repeated flashbacks. In Memoranda, merely handling his blood-stained notebooks caused the war to return: "I can never turn their tiny leaves, or even take one in my hand, without the actual army sights and hot emotions of the time rushing like a river in full tide through me. . . O Out of them arise active and breathing forms. They summon up, even in this silent and vacant room as I write, not only the sinewy regiments and brigades, marching or in camp, but the countless phantoms of those who fell" $(P W, 1: 320)$.

The question for Whitman and his various interpreters seems to be, as Katherine Kinney asks, "What is to be done with the bodies"13 that return like phantoms? By this she means individual bodies, the body politic, and Whitman's own body. The difficulties inherent in depicting these various bodies, in turn, raise the question of how to represent the war, much less redeem it. Timothy Sweet argues that poetic and photographic representations of the war are able to accomplish a series of redemptive exchanges: wounds are transformed into ideology, and broken individual bodies are exchanged for an intact union and national landscape. Drum-Taps and Sequel to Drum-Taps do manage to remain largely optimistic regarding their ability to represent and aestheticize the conflict and the justness of the conflict itself.

\section{Drum-Taps: The Poetry of War}

In Whitman's poetry about the Civil War, published in Drum-Taps and Sequel to Drum-Taps, he managed to make sense of the war, through variously naturalizing, typifying, personalizing, and describing it in sublime terms. Several of what Erkkila terms the early "mobilization poems" were unabashedly romantic and optimistic regarding the ability of the "ruthless force" of the war to wake America from its preoccupation with such narrow everyday concerns as commerce, gossip, and farming. ${ }^{14}$ In poems such as "Beat! Beat! Drums!," Whitman chose war over a union based on such selfish values as property and the pursuit of profit. 
In many of these early poems Whitman was enthralled by the martial, rhythmic beat of drums and the ideological power of the American flag. And the poem that Whitman settled on as the last one in his final arrangement of the "Drum-Taps" sequence, "To the Leaven'd Soil They Trod," imagined a sort of pastoral rebirth, a healing and making whole of the national landscape and the union.

Several poems in between these initial ones, full of blustery romanticism about war itself, and the final poem with its vision of the earth purifying itself, doubted the ability of poetry to represent the war. Although Sweet argues that Drum-Taps manages to recuperate the war by relying on rhetorical tropes of typification to produce sense and legitimacy, this process is problematic. Sweet notes that typification problematizes "representation in both the political and the poetic-mimetic senses" (13). He suggests that in exchanging dead, typified bodies and representative incidents for the ideology of union that "the body disappears into an ideological construct" (16).

In "To a Certain Civilian," the combative speaker asks: "Did you ask dulcet rhymes from me? / Did you seek the civilian's peaceful and languishing rhymes?" ( $L G, 323)$. In the face of war the poet cannot produce conventionally pleasing rhymes; rather he must write different sorts of poems or prose of the sort in Specimen Days. Elsewhere it is clear that the war also deformed the human body. In "A March in the Ranks Hard-Prest, and the Road Unknown," Whitman noted that the "bloody forms" of wounded soldiers in an impromptu hospital were "a sight beyond all the pictures and poems ever made" ( $L G, 305)$. While the war here turns individual bodies into incomprehensible "bloody forms," Whitman was able to accommodate this through a rather conventional rhetoric of the sublime. Thomas in "Fratricide and Brotherly Love" argues rather differently that Whitman works to record anonymous suffering and "wherever possible, to restore to those soldiers at least a trace of that personal identity that had been almost obliterated by the new techniques of mass warfare." 15 Thomas suggests that several of the Drum-Taps poems "enact a psychically healing process of bestowing a kind of identity on some poor unknown through a glance of sympathetic human recognition" (39). In Memoranda, Whitman neither appealed to the sublime nor to the restoration of individual identity to make sense of the carnage.

Several poems later, in the convulsive "Year That Trembled and Reel'd Beneath Me," Whitman is so shaken that he asked:

Must I change my triumphant songs? . . .

Must I indeed learn to chant the cold dirges of the baffled?

And sullen hymns of defeat? $(L G, 308)$ 
The very next poem in Whitman's final arrangement, "The WoundDresser" (originally "The Dresser"), is the center of Drum-Taps and Whitman's answer to the previous questions. "The Wound-Dresser" suggests that while Whitman must back away from the free-wheeling optimism of, say, "Song of Myself," he does not need to retreat wholly and offer only cold dirges and hymns of defeat. ${ }^{16}$ "The Wound-Dresser," as revised in the final edition of Leaves, records Whitman's initial misguided optimism and excitement regarding the war as well as his subsequent response:

(Arous'd and angry, I thought to beat the alarum, and urge relentless war, But soon my fingers fail'd me, my face droop'd and I resign'd myself, To sit by the wounded and soothe them, or silently watch the dead). . . (LG, 309)

Whitman spent much of the war silently watching and soothing the wounded, and in this poem we see him arriving at this role. ${ }^{17}$ The speaker of the poem, seemingly Whitman himself, is called on to remember the war and to tell the children of it. In the second section of the poem he begins telling his audience of battles and charges, but then he switches to a rather different sort of recollection:

\section{... in silence, in dreams' projections,}

While the world of gain and appearance and mirth goes on,

So soon what is over forgotten, and waves wash the imprints off the sand,

With hinged knees returning I enter the doors. . . . $(L G, 310)$

Here Whitman returns to the hospital, and "The Wound-Dresser" registers the convulsive and involuntary quality of his wartime memories, as dreams of the war return unwilled. The motion of the poet's body is also unwilled and machinic, as indicated by the ugly and mechanical phrase "with hinged knees." Whitman urges the reader to "be of strong heart" and to follow him into the hospital, as he is concerned that the war, now that it is over, not be quickly forgotten. Indeed, the rest of the poem is designed to ensure that the next generations do not forget the war. But rather than showing the war as heroic or as a lofty struggle of values and beliefs, Whitman focuses on the body of the average soldier. "The Wound-Dresser" records Whitman's disillusion with battles and heroics, his realization that each side was "equally brave," and his turn towards the hospital, which he declares in Specimen Days was the "marrow" of the entire conflict.

Many of the representational and ideological problems raised and then summarily dealt with in Drum-Taps are treated more thoroughly in Memoranda and Specimen Days. Sweet suggests that, "The Memoranda are more reflective than Drum-Taps, sometimes critical and even skepti- 
cal about the possibilities of representation. They appear to be working through those rare moments in Drum-Taps in which the war is said to pose representational problems, in an attempt to find aesthetic and ideological solutions" (46). Sweet also notes that "It is not until well after the war, and then only in his prose that Whitman comes close to admitting that the war dramatized the instability of ... [the] topos" that equated body and text (21).

\section{“blood smutch'd little note-books": The Prose of the War}

On the very first page of Memoranda During the War, Whitman described his writing process and made a series of analogies between the war's effects on the body and its effects on literary form:

From the first I kept little note-books for impromptu jottings in pencil to refresh my memory of names and circumstances. . . . In these I brief'd cases, persons, sights, occurrences in camp, by the bedside, and not seldom by the corpses of the dead. Of the present Volume most of its pages are verbatim renderings from such pencillings on the spot. Some were scratch'd down from narratives I heard and itemized while watching, or waiting, or tending somebody amid those scenes. I have perhaps forty such little note-books left, forming a special history of those years, for myself alone, full of associations never to be possibly said or sung. I wish I could convey to the reader the associations that attach to those soil'd and creas'd little livraisons, each composed of a sheet of paper or two, folded small to carry in the pocket, and fastn'd with a pin. I leave them just as I threw them by during the War blotch'd here and there with more than one blood-stain, hurriedly written, . . . lurid and blood-smutch'd little note-books. $(P W, 1: 2)$

These hasty, bloody, and allegedly unedited scratchings reflect the conditions of their production-impromptu hospitals - and that which they are chronicling, the often arbitrary fate of individual bodies. ${ }^{18}$ Whitman described his writings as "scratchings," linking writing and wounding. ${ }^{19}$ In the 1860 edition of Leaves of Grass in "Calamus" 15, Whitman represented writing as an eroticized wounding that frees his imprisoned thoughts; the destroyed bodies of soldiers made this metaphor grotesquely literal and unworkable. ${ }^{20}$ Indeed, the material form of Whitman's original writings resembled a wound-dressing or bandage, as he wrote on folded sheets of paper that sometimes became blood-stained and were fastened together with a pin.

Whitman also characterized his wartime writings as fragmentary and disjointed; they threatened to fall apart, like the nation. Sweet points out that a memorandum etymologically is "something that ought to be remembered (in the future); it is not so much a description as a prescriptive agenda for memory" (47). He argues that "the very notion of a memorandum implies that the text is not thoroughly adhesive" (48). Indeed Whitman produces not a neatly bound, complete book, but a 
series of "soil'd and creas'd little livraisons." The Oxford English Dictionary, which cites Whitman's use of the word as an example, defines livraison as "A part, number, or fascicule (of a work published by installments)." ${ }^{21}$ Livraison comes from the Latin verb liberare, meaning to deliver or liberate. ${ }^{22}$ Both senses of the word are important here: Whitman is concerned with delivering a narrative of the war and with liberating the nation from the war. However, it is difficult to imagine how "these soil'd and creas'd livraisons" (7), these installments, could cohere and how they might provide deliverance from the war.

\section{"one vast central hospital"}

Whitman wrote that "it seem'd sometimes as if the whole interest of the land, North and South, was one vast central hospital" (PW, 1:117). The various hospitals where Whitman volunteered are the main, and certainly the most important, setting of his prose writings about the war. Whitman was attracted to the hospital for a number of reasons. Thomas argues that Whitman's “deep mistrust of the power of money in the booming capitalist society of the North led him to emphasize that a different 'currency' circulated in the hospitals-a currency of love and affection." 23 The hospital was also a place where civilians and soldiers mixed and where rebel and union soldiers might even be housed in adjacent beds. The hospital thus allowed Whitman to see something that the North and South shared, something that united them; this something was the individual human unit, the wounded body.

Despite these compensatory virtues, the hospital showed how Whitman's poetic vision breaks down under the pressures of war. I thus disagree with critical accounts, such as Sweet's, that downplay the importance of the hospital and instead emphasize battlefields and the pastoral landscape. I also disagree with critical accounts, such as Robert Leigh Davis's and to a lesser extent Mark Maslan's and Peter Coviello's, that view the hospital drama in an idealized or romanticized light and thus see it as the realization of Whitman's interest in the body, rather than its nightmare inversion.

Sweet's chapter, in Traces of War, on Whitman's prose writings about the Civil War focuses on the relatively few scenes in Memoranda that depict death on the battlefield. He pays scant attention to the many deaths in the hospital, removed from the battlefield and its associations with heroism and ideology. Sweet discusses a passage from Memoranda in which a soldier "crawls aside to some bush-clump, or ferny tuft, on receiving his death-shot - there, sheltering a little while, soaking roots, grass and soil with red blood" (quoted in Sweet, 50). He argues that this death is represented "as a violation of pastoral harmony and tranquility" (56), but that "the naturalizing power invested in the nurturing 
land itself covers the traces of that war" (57). While I agree with Sweet that this "pastoral framing of the corpse" is an attempt to "cover the ideological loss threatened by potentially meaningless violence" (65), I see Whitman as not even attempting such ideological recuperation in his representation of the hospitals, which are the main setting of Memoranda and the "marrow" of the war.

A more egregious and dangerous misreading of Whitman's writings about the hospital is found in Davis's Whitman and the Romance of Medicine. It is worth quoting Davis at some length:

Consequently, my chief concern is to show how Whitman construed the liminality of convalescence as an analogue for a democratic political process. Odd as it may at first appear, Whitman, I argue, likens the ideal democratic polity to an infirm, rather than a healthy, body. He construes as a restorative political value the incompleteness and uncertainty of the suffering body, a body subject to constant change and rendering provisional the conditions of its care. Whitman promotes this incompleteness as an analogue for the desirable instability of the democratic state. Like the makeshift hospitals in which he worked and wrote during the war, democratic government is itself provisional, necessarily subject to the uncertainty of a body politic never wholly comprehended by its own representative figures. ${ }^{24}$

Davis argues that the open-ended and uncertain nature of democracy somehow has its correlate in the open-ended and uncertain nature of the hospital. He further links the democratic body politic to homosexuality and to the wounded body; he valorizes all three as "oscillating, uncommitted, and aloof" (34).

Davis takes literally Whitman's metaphoric fascination with bodily flux, illness, and incompleteness. This is a mistake, for whereas Whitman does elsewhere embrace contradiction and change and even likens democracy to flux, nowhere is there the sense that he wants these metaphors to be literalized in any one body..$^{25}$ In concretizing and literalizing metaphors, particularly bodily metaphors, the war exposed their limits. While Davis's reading of the hospital as a homoerotic site most certainly seems right, I think this is merely compensatory and Whitman is not valorizing the hospital as a utopic site of "ceaseless play" (21).

Coviello, in his introductory essay to a recent edition of Memoranda During the War, also argues that the war caused some of Whitman's key metaphors to become literalized, and he views this positively. For instance, Coviello notes that in "Whoever You Are Holding Me Now in Hand," part of the "Calamus" cluster, Whitman imagines himself as a book. Whitman describes an erotics of literary circulation in which he is a book thrust into his reader's breast and hip pockets, touched and carried. Coviello argues that Whitman's wartime activities are consonant with this fantasy of circulation: "In Memoranda, Whitman no longer circulates anonymously, in the form of his body-caressing book, but 
physically, in person, moving one-by-one through the ranks of special young American men and offering to each all his passionate affection. . . . Whitman ... [produces] cohesion, bed by bed, soldier by wounded soldier." ${ }^{26}$ Coviello continues: "It is in this sense that critics such as Michael Moon and Betsy Erkkila see in Whitman's Civil War experiences not a cancellation but an extension of the ideals of the 'Calamus' poems" (xlii).

I see these literalizations as explicit signs that Whitman's democratic poetics was failing him. The circulation of Whitman as book in the "Calamus" poems has a power and degree of extension that is lacking in Whitman's literal circulation amongst the war wounded. There is only one Whitman body and thus his task of visiting the wounded will never be completed. Whitman's books, on the other hand, have powers of multiplication and circulation far beyond those of the human body.

As stated earlier, I see Whitman's representations of the hospital not as the realization of his democratic poetics but as its inversion and an exhibit of its failure. Whitman typically spoke for the wounded soldiers. Some of this is due to the diary-like format of Memoranda, in which verbatim dialogue might be out of place. At other times the soldiers' silence can be explained by the simple fact that they are physically unable to speak. Whitman observed, "Thomas Haley ... a regular Irish boy ... shot through the lungs - inevitably dying . . . It is useless to talk to him, as with his sad hurt, and the stimulants they give him . . . the poor fellow even when awake, is like some frighten'd, shy animal" ( $P W$, 1:49-50). In "Some Specimen Cases," Whitman gives the case history of Marcus Small. Both Small and Whitman think Small will die soon and Whitman notes: "I let him talk to me a little, but not much, advise him to keep very quiet - do most of the talking myself . . . talk to him in a cheering, but slow, low and measured manner" (PW, 1:51). While no doubt Whitman is attempting to prescribe the most curative course of action for Marcus, I think something more is going on. As Elaine Scarry notes in The Body in Pain, pain is indisputably real for the suffering individual but has only a tenuous existence for others. Scarry writes that pain's "resistance to language is not simply one of its incidental or accidental attributes, but essential to what it is." ${ }^{27}$ It is difficult to communicate pain and Whitman runs up against this intersubjective barrier in treating wounded soldiers. Whitman was the author of these soldiers' hospital experiences, and he often scripted their dying, ensuring that these men died courageously and that they could thus be exhibits of democracy, not simply of senseless violence.

I would suggest that it is not only despite but because of their silence that Whitman feels he knows the soldiers so well. Louisa May Alcott's Hospital Sketches (1863), which was read by Whitman and provided a model for his own writings, contains an interestingly parallel 
incident. ${ }^{28}$ As she watches over sleeping men, much as Whitman did, she concludes:

Some grew stern and grim, the men evidently dreaming of war, as they gave orders, groaned over their wounds, or damned the rebels vigorously; some grew sad and infinitely pathetic, as if the pain borne silently all day, revenged itself by now betraying what man's pride had concealed so well. . . . [M] any almost seem to speak, and I learned to know these men better by night than through any intercourse by day. . . . [T] hough they made no confidences in words, I read their lives. ${ }^{29}$

Alcott thinks she is able to read the lives and access the inner thoughts of these silent or inarticulate men more thoroughly even than if they could speak. The men who Alcott reads are unable to contest her conclusions about their character and emotional state. An identical dynamic was at play for Whitman. For both authors the wounded soldiers became objects awaiting captions.

Maslan in Whitman Possessed also argues that for Whitman, the Civil War literalized what was previously metaphoric. Maslan's argument that Whitman represents poetic inspiration as homosexual penetration and furthermore offers this as the ground for his authority and license to speak, is deeply persuasive. But while Maslan seems to see the war logically extending Whitman's earlier figurations of inspiration, desire, and poetic representation, I see a crisis. According to Maslan, Whitman's poetic authority was based on his ability to be inspired and speak for others. Maslan notes that many of Whitman's Civil War poems are "concerned with intimate transactions occurring between the poet-speaker and the soldiers" (124). Maslan describes these eroticized exchanges as "transferential" in that they feature an exchange between poet and wounded, often dying soldiers. For Maslan, this transferential logic is "the structure of poetry's popular authority" (125) and seemingly the same logic that he sees at work in "Song of Myself" and other earlier Whitman works; however, I see the transferential structure at work in Drum-Taps and Memoranda as very different, as in these cases poetic inspiration is drawn from the dying and the wounded. I would describe this as essentially vampiric rather than transferential. ${ }^{30}$ Whitman's wartime writings, particularly his prose writings, mark the moment when this model of inspiration tips over into horror. Maslan's own logic highlights this. $\mathrm{He}$ claims that for Whitman, poetic inspiration was "a form of sexual intercourse" (21); so, if this model holds then Whitman's eroticized inspiration would seem to take a rather morbid and necrophilic turn during the war.

In representing the wounded in the hospital, Whitman achieved order only through sacrificing individual particularity and subjectivity. The wounded soldiers were linked to objects and described as "collec- 
tions" ( $P W, 1: 66)$. Both Whitman and hospital administrators faced archival and organizational challenges. Whitman achieved some order and classified the wounded by representing them as types and objects. He usually referred to the men only by their initials and their regiment, and sometimes does not even provide this detail. Whitman also repeatedly referred to the men as "types," "cases," and "specimens," making it so that each individual body comes to stand for more than just itself. In Whitman's representations of the hospital the individual is implicitly condensed, typified, and objectified.

\section{A Fascinating Site}

While the affinity of the wounded body to an object is implied throughout Memoranda, it is made explicit in the section entitled "Patent Office Hospital." Whitman describes a hall in the Patent Office, previously a national museum, but transformed out of necessity into a hospital ward. Construction of the impressive neoclassical Patent Office building was begun in 1836 and completed in 1868; it was the first federal exhibition hall in Washington D.C. and is now home to the National Portrait Gallery and the Smithsonian American Art Museum. Whitman wrote concerning the wartime display in the museum become hospital:

I must not let the great hospital at the Patent office pass away without some mention ... It was strange, solemn, and, with all its features of suffering and death, a sort of fascinating sight. I go sometimes at night to soothe and relieve particular cases. Two of the immense apartments are fill'd with high and ponderous glass cases, crowded with models in miniature of every kind of utensil, machine or invention, it ever enter'd into the mind of man to conceive. ... Between these cases are lateral openings, perhaps eight feet wide and quite deep, and in these were placed the sick, besides a great long double row of them up and down, through the middle of the hall. Many of them were very bad cases, wounds, and amputations. ( $P W, 1: 30-31)$

In this fascinating passage, Whitman puns with the word "cases," using it to indicate both the vitrines in which objects are displayed and the wounded soldiers. Whitman's gallows humor is also evident in his punning section title (added to one section of Memoranda when he included it in Specimen Days), "Unnamed Remains the Bravest Soldier" ( $P W$, $1: 48)$. Both instances of grim humor are concerned with the individual body becoming a thing.

While I have been arguing that the wounded bodies are objectified in so far as they are often denied voice and turned into types, here, in their display and treatment, they are equated with objects and particularly with machines. Prior to being pressed into service as a hospital in October 1861, after the battles of Second Bull Run, Antietam, and Fredericksburg began flooding Washington with wounded, the Patent 
Office Museum was used as an army barracks. An article in Harper's Weekly of June 1, 1861, shows a lithograph (Figure 1) of the members of the First Rhode Island Regiment sleeping on bunk beds stacked three high, between display cases. At this early moment of the war the author is optimistic and quite comfortable with comparing the soldiers to machines: "Never since American inventive genius was first aroused did the Patent Office contain such remarkable models of American manufacture as those which now sleep three deep in 'bunks' spread along the edges of the cabinets." 31

Indeed this linking of bodies and manufacturing is similar to some of Whitman's comments about democracy and industry. For instance, in Democratic Vistas he employed an industrial and technological vocabulary to discuss how the nation coheres. He wrote that one of the main roles of the national poet is in "fusing contributions, races, far localities, \&c., together" ( $P W, 2: 368)$; democracy is described as having a "successful working machinery ... [that produces] aggregate America" ( $P W, 2: 392)$; and he referred to the United States as "those thirty-eight or forty empires solder'd in one" $(L G, 565)$. For Whitman, democracy was related to industry and machinery only metaphorically. When the war began to concretize and particularize some of these machinic and industrial metaphors in the bodies of individual soldiers, he recoiled in horror.

Part of this horror is that during the war it was not democracy that was machinic but the individual body. Whitman imagined that democracy has a "working machinery," although he seems to mean this only in the broadest of terms: that is, Whitmanian democracy is, according to Donald Pease, always working to realize what can be. ${ }^{32}$ So if democracy is a machine that works repetitively and involuntarily, its work is of the broadest sort.

While Whitman is most certainly writing about bodies and machines, I should note that this is different from the relationship Mark Seltzer describes so trenchantly in Bodies and $\mathrm{Ma}$ chines. Whitman wrote during a period that was still looking ahead to the age of "machine culture" 33 that blossomed around the turn of the century. According to Seltzer the age of machine culture is marked by a "radical and intimate coupling of bodies and machines" (13). These turn-of-the-century

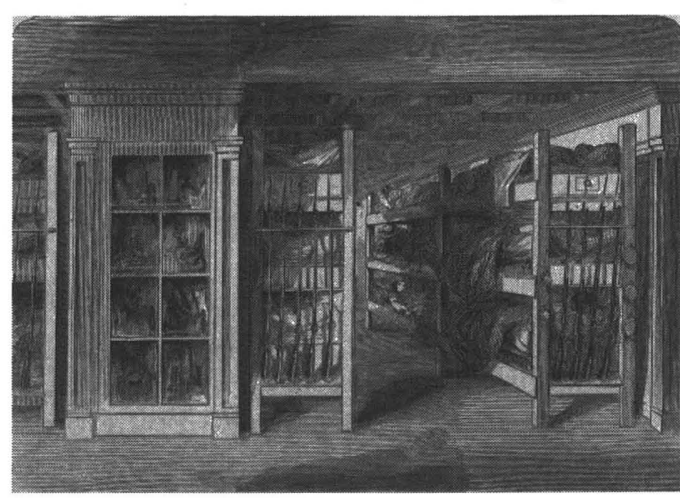

Figure 1 
couplings produce "the unlinkings of motion and volition that allow hysteria, locomotion, and machine-work to communicate with each other" (17). Sometimes this even produces subjects whose volitionlessness is valorized-as in Buck in Jack London's The Call of the Wild - or at least who are able to continue working-as in London's "The Apostate," in which a child laborer becomes a perfectly efficient work machine.

Within Whitman's writings the body and the machine cannot be so radically coupled. In fact, in Democratic Vistas Whitman argued that the poet must resist technology, the machine, and the attendant homogenization. He warned that these tendencies seem "with steam-engine speed, to be everywhere turning out the generations of humanity, like uniform iron castings" (PW, 2:424). In Specimen Days and Memoranda the coupling of body and machine produces bodies that cease to work, bodies that simply convulse.

In one of the more horrifying incidents in Memoranda, we are shown a wounded body that bears the signature of technology and has become a broken machine. Whitman recounted how a rebel soldier "was mortally wounded top of the head, so that the brains partially exuded. $\mathrm{He}$ lived three days, lying on his back on the spot where he first dropt. $\mathrm{He}$ dug with his heel in the ground during that time a hole big enough to put in a couple of ordinary knapsacks" ( $P W, 1: 76)$. Here the body, like a machine, can only do a single thing that it carries out repeatedly and involuntarily.

Louisa May Alcott also described a wounded soldier who became a sort of machine, not just in his physical actions but in his mental processes: "A slight wound in the knee brought him there; but his mind had suffered more than his body; some string of that delicate machine was over strained, and, for days he had been reliving in imagination, the scenes he could not forget" (45). The soldier's mind obsessively remembers his traumatic experiences. In Memoranda Whitman also writes of a soldier who suffers flashbacks and in "The Artilleryman's Vision," included in Drum-Taps, a soldier relives the war in troubled dreams. ${ }^{34}$

What does this jarring juxtaposition of bodies and machines in a museum-become-hospital signify? Katherine Kinney sees an opposition between how Whitman's prose handles the bodies of the wounded and how the museum display handles the objects which it displays, arguing that " $[t]$ he withering flesh and the objective display of the museum mark precisely this loss of sensuality - a loss countered by the 'bodily excess' of Whitman's war prose in which injury and his response to it, including writing, remain 'sensuous human activity"' (182).

I see Whitman's prose, though, as of a piece with the fragmenting and objectifying force of the museum's displays. The war along with Whitman's particular mode of representation turned the bodies of sol- 
diers into objects. I have already suggested that some of the order Whitman attains in his representation of the hospitals is produced by leaching the body of its individuality and condensing the wounded soldiers into types, specimens, and cases. The bodies that Whitman displays in Memoranda show not 'sensuous human activ-

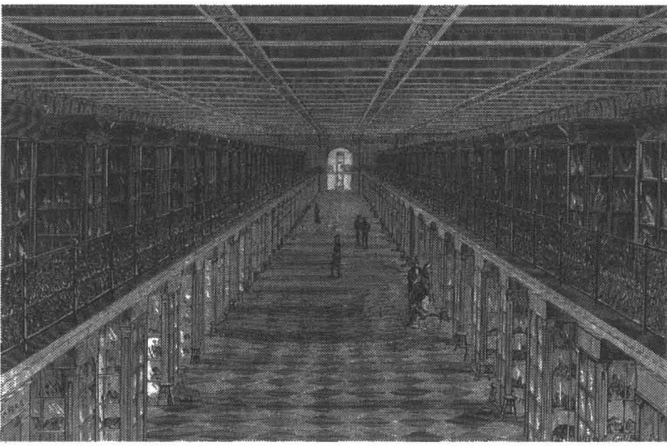

Figure 2 ity,' but what technology, particularly military technology, can do to human bodies. The bodies that Whitman turns into types, specimens, and exemplary cases strike me as very similar to the objects on display in the Patent Office Museum. The model room of the Patent Office (Figure 2) displayed the models that inventors submitted along with their patent applications. These devices were prototypes for a larger scale production run. Whitman employed a rhetorical condensation that followed a similar logic; according to his rhetoric, each wounded soldier stands for hundreds if not thousands of other casualties. The soldiers represented in Whitman's writings are themselves models; moreover, they attest to the encounter of a body with a machine.

In "Song of the Exposition" (1871), a poem written for the fortieth annual exhibition of the American Institute in New York, Whitman imagined that war will be replaced by triumphant displays of industry:

Away with themes of war! away with war itself!

Hence from my shuddering sight never more return that show of blacken'd, mutilated corpses!

And in its stead speed industry's campaigns,

With thy undaunted armies, engineering .... $(L G, 201)$

It is significant that, in this poem about the display of industry, war figures so prominently. Whitman seems to acknowledge that industry, which can produce railroads, buildings, and even "Union holding all, fusing, absorbing, tolerating all" ( $L G, 203)$, can also produce "blacken'd, mutilated corpses!"

The question then is how to move from "blacken'd, mutilated corpses!" to "Union holding all, fusing, absorbing, tolerating all." In Memoranda, Whitman saw no easy way to do this; he recalled, parenthetically, that "it seem'd sometimes as if the whole interest of the land, North and South, was one vast central hospital, and all the rest of the affair but flanges" ( $P W, 1: 117)$. A flange is a piece of industrial hard- 
ware: "A projecting flat rim, collar, or rib, used to strengthen an object, to guide it, to keep it in place, to facilitate its attachment to another object, or for other purposes" (OED). The hospital with its wounded bodies was, for Whitman, the important part of the war. By terming "the rest of the affair but flanges," I take Whitman to mean that the war's battles and its ideological differences were merely technologies for recuperating the wounded. That is, heroism, sacrifice, and ideology were "flanges" that could be attached to the war so that the bodies in the hospital could be viewed as serving some purpose. As stated earlier, I believe that Whitman was skeptical of such easy ideological recuperation. Whitman stated that the hospitals are the center of the war, and while his writings attested to the soldiers' heroism, they made no distinction between union and rebel.

It is important to note that the soldiers in the Patent Office were displayed in what was a museum. A museum is a place of memory that aims to reconstruct some sort of unity out of lifeless fragments. Museums often seek to remember and reanimate that which has passed. Certainly Whitman's writings about the war were concerned with how to display, memorialize, and remember the war. Before characterizing more finally and definitively the mode of display at which Whitman arrives, it is necessary to examine some other modes of display and memorialization that he rejects.

\section{Modes of Display and Memorialization}

The war can and did lead to various displays and implicit and explicit memorials. I would like to discuss briefly several of these different strategies: museum display, freakish spectacle, and photography. I argue that Whitman implicitly and at times explicitly argued against these modes of memorializing the war.

Whitman likened the Patent Office Museum's display cases to the cases of the wounded soldiers he treats. Both, I have argued, are marked by a loss of wholeness and individuality; the machines and bodies are both models that stand in for many other examples. The Civil War did, in fact, lead to museum displays not so different from the displays in the Patent Office Museum. Kinney notes that the Army Medical Museum, which opened in 1867 in Ford's Theater-the site of Lincoln's assassination-displayed specimens "in glass cases very similar to those in the Patent Office, fulfilling the eerie sense of the wounded as part of the technological display hidden in Whitman's description of the hospital" (182)..$^{35}$ According to Mary Clemmer's Ten Years in Washington (1874), the Army Medical Museum was designed to let people "behold what war, disease, death, and human skill had wrought." 36 I would add technology to this list. 
The Army Medical Museum displayed grisly Civil War specimens and became a sensationalistic tourist attraction. Ames notes that the museum showcased horrors such as a withered arm from the Battle of Gettysburg (478); "freaks of bullets and cannon-shot" (480), including two vertebrae pierced lengthwise by a carbine ball; a tibia shattered by a round shell; and a four-inch section of hip-bone that a soldier lost in battle but was miraculously able to walk afterward (484). ${ }^{37}$ The museum, like Whitman's Memoranda, shows what war's technologies did to the body.

But there was an important difference between the museum and Whitman's writings. The Army Medical Museum's displays became freakish tourist attractions, visited by 25,000 people per year (Ames, 476). Kinney argues that these displayed objects are "alienated commodities and spectacles of mass culture which owe more to Barnumism than to principles of scientific classification" (182). I don't think this was the sort of remembrance or notoriety that Whitman sought to bestow upon the war. Representing the war wounded as Barnumesque freaks would replace the war's convulsiveness with a mere frisson of voyeuristic curiosity.

While the mere presence of walking and hobbling veterans served as a memorial to the war, images of the wounded were also reproduced in cartes de visite. ${ }^{38}$ Bill Brown's observation that photographs of freaks and wars were widely consumed and thereby "absorbed into the domestic everyday" 39 certainly applies to such images. Alan Trachtenberg, in "Albums of War," also argues that images of the Civil War, particularly stereographic images, were consumed in the parlor and became a part of "bourgeois domestic life," allowing for the strange to appear "safely and as if for one's own delectation, directly within the sphere of the familiar." 40 It is not a coincidence that Mathew Brady, one of the preeminent photographers of the Civil War, also photographed freaks. ${ }^{41}$ Brady's studio was located across the street from P.T. Barnum's American Museum, and he photographed Tom Thumb, Chang and Eng, and the Fiji Cannibals, among other notable freaks. According to Seltzer, such sensationalized images of bodily oddity, deformity, and injury are part of "The Pathological Public Sphere."42 Whitman's project seems fundamentally different, seeking not to sensationalize, demonize, or commodify different bodies but to understand and include them within democratic American.

As well as being critical of the practices of freakery, Whitman was also critical of photography. In Democratic Vistas, Whitman described poetry in opposition to photography, characterizing poetry as "(No useless attempt to repeat the material creation, by daguerrotyping the exact likeness by mortal mental means)" (PW, 1:419). Whitman saw this mimetic image-making as able to "breathe into ... [art] the breath of 
life," but only after "all the other parts of a specimen of literature or art are ready and waiting" ( $P W, 1: 419)$. Mimetic verisimilitude alone was inadequate and when it comes to the war, I would argue, dangerous.

Sweet notes that "[p] oetic and photographic representations of the war aided political discourse in the projects of legitimating the violent conservation of the Union by reflecting on and participating in the transformation of wounds into ideology during and after the Civil War" (2). It is precisely the transformation of wounds into ideology that Whitman, in representing the war as convulsive, was trying to stymie. While Whitman discussed the war in photographic and imagistic terms several times in Memoranda, these are moments of misrepresentation. He noted that " $[t]$ his night scrimmage was very exciting, and afforded countless strange and fearful pictures" ( $P W, 1: 45$; emphasis added). In the following passage, Whitman described a single photographic glimpse that offers a very misleading sense of the entire scene:

The night was very pleasant, at times the moon shining out full and clear, all Nature so calm in itself, the early summer grass so rich, and foliage of the trees-yet there the battle raging, and many good fellows lying helpless, with new accessions to them, and every minute amid the rattle of muskets and crash of cannon ... the red life-blood oozing upon that green and dew-cool grass. ( $P W, 1: 46)$

Here Whitman found himself lingering lovingly on the natural beauty of this scene as if it were a pastoral idyll or a peaceful nocturne. He catches himself in mid-description, and after the dash his attention shifts back to his constant war-time preoccupation: wounded bodies.

When Whitman interrupted himself, he was in the process of naturalizing the war, linking it to "nature" and thus to a cyclical, seasonal temporality that promises rebirth. In Memoranda, Whitman took pains not to naturalize or aestheticize the war as he did in Drum-Taps (for instance in "To The Leaven'd Soil They Trod") and Sequel to Drum-Taps (notably in "When Lilacs Last in the Dooryard Bloom'd"). ${ }^{43}$ Some of Melville's battlefield poems, especially the beautiful "Shiloh: A Requiem," also elegized the war by linking it to a natural cycle of rebirth. In

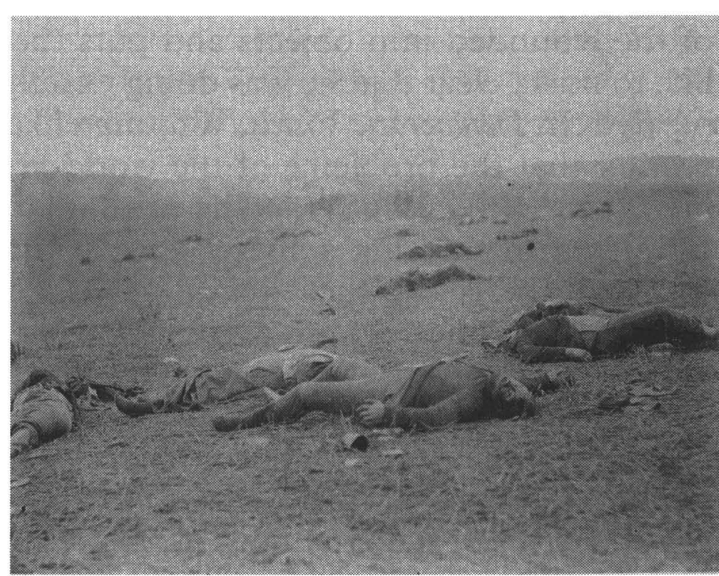

Figure 3 
Melville's poem, the scars of an extremely bloody battle are mitigated by the return of swallows and the healing April rains.

This peculiar and oddly peaceful beauty is found most often in photographic representations of the war. To be sure, there were purely horrific images such as stereographs of ditches filled haphazardly with overlapping layers of dead bodies. ${ }^{44} \mathrm{~A}$ prime and widely reproduced example of a photograph that aestheticizes and naturalizes the war, however, is Timothy O'Sullivan's A Harvest of Death, Gettysburg, Fuly, 1863 (Figure 3). ${ }^{45}$ Dead bodies rest on a sloped battlefield, spaced out as if simply sleeping. Several figures on horseback, who seem to stand guard over the scene, are visible in the background, obscured by mist or smoke. Photographs such as this can be partially explained by the fact that long exposure times precluded images of battle; but, as Sweet argues, there was a proscription against photographing the moments of suffering between life and death (109). It is precisely these moments that Whitman is most interested in.

Whitman does not want us to be able to see such beauty in the war. In Harvest of Death we are, as Sweet suggests, able to exchange dead bodies for intact ideology; that is, the photograph preserves conventional notions of heroism, sacrifice, and the glory of dying for one's country. Whitman, in describing the war as convulsive and seeking a convulsive mode of representation, is trying to prevent such ideological exchanges and recuperations. For Whitman, bodies that convulse can only properly be themselves; they can only attest to their broken particularity and cannot be made to do metaphorical or ideological work.

\section{$A$ Therapeutics of Display}

I've painted a rather grim picture of how Whitman turns the bodies of the wounded into objects and puts them on display. Now I would like to make clear that he was doing exactly what he thought the nation needed. In Democratic Vistas, Whitman likened literature to a cure, suggesting that the problems of the world are to be "met and treated by literature" ( $P W, 2: 365)$, and he urged that we look at the nation "like a physician diagnosing some deep disease" ( $P W, 2: 369)$. Given that Whitman suggested that literature was a cure and the nation a potentially diseased body, I am arguing that he imagined that his display of wounded bodies - of the nation, feverish, in the hospital, and in danger of requiring amputation - would have a salutary effect. Again, the word convulsiveness is crucial. For Whitman the war continued to be convulsive. As late as 1888 , when asked if he thought back to the days of the war, he replied, "I do not need to. I have never left them. They are here, now. . .."46 
Indeed when Whitman returns to the Patent Office, which as well as housing wounded bodies was also the site of Lincoln's second inaugural ball, he is overwhelmed by memories of the wounded bodies that were previously held there:

I could not help thinking, what a different scene they presented to my view a while since, fill'd with a crowded mass of the worst wounded of the war. . . . To-night, beautiful women, perfumes, the violins' sweetness, the polka and the waltz; then the amputation, the blue face, the groan, the glassy eye of the dying, the clotted rag, the odor of wounds and blood. (PW, 1:95)

Whitman was, I think, aiming to display the war in such a way that its convulsiveness would be preserved. In this instance, the convulsiveness of Whitman's unwilled memories_-"I could not help thinking"-of the wounded bodies cuts through the ideologically charged spectacle of the inaugural ball. Again, Whitman was arguing that the truth of the war is wounds, bloody rags, and groaning, dying bodies. Whitman aimed to impart some of this convulsiveness to his readers. Thomas argues that Whitman's Civil War activities were intended to make his civilian readers "co-respondent, with the soldiers, to the redemptive anguish involved." 47 While I agree with this assessment of Whitman's wartime aims, I see no redemptive aspects to this anguish, at least not in his prose writings.

We can understand Whitman's assertion that convulsiveness is the word which best describes the war as a way of saying that the war was a trauma. Trauma, although it is etched in one's memory, cannot initially be assimilated to experience. The unassimilable nature of trauma helps make sense of the fragmented form and rawness of Memoranda During the War and Specimen Days. Trauma is also marked by an insistent literality; unlike a dream in which the significance is disguised, traumatic memories are straightforward and rarely metaphoric. Caruth comments that

modern analysts ... [as well as Freud] have remarked on the surprising literality and nonsymbolic nature of traumatic dreams and flashbacks, which resist cure to the extent that they remain, precisely, literal. It is this literality and its insistent return which thus constitutes trauma and points towards its enigmatic core: the delay or incompletion in knowing, or even in seeing, an overwhelming occurrence that then remains, in its insistent return, absolutely true to the event. ${ }^{48}$

For Whitman, the wounded bodies must remain simply wounded bodies, and this is the truth of the war that ought to be shared. Caruth also suggests that "the history of trauma, in its inherent belatedness, can only take place through the listening of another" (11). In representing the war convulsively, Whitman was seeking to have the war understood 
as trauma and not as recuperable or redeemable. He didn't want the war to be forgotten, nor did he want us to romanticize or aestheticize the war as certain modes of poetic, photographic, and material representation allowed.

Whitman's prose representations of the war, then, function as warnings against war and disunion. They also warn readers to be skeptical of ideological glosses of the war. In Democratic Vistas, Whitman called for active and suspicious reading:

Books are to be call'd for, and supplied, on the assumption that the process of reading is not a half sleep, but, in the highest sense, an exercise, a gymnast's struggle; that the reader is to do something for himself, must be on the alert, must himself or herself construct indeed the poem, argument, history. ( $P W, 2: 424-425)$

An active and skeptical reading of Memoranda shows the war to be a "poem, argument, history" about bodies that have stopped working, bodies that convulse.

\section{Stanford University}

\section{NOTES}

1 Walt Whitman declared that "[ $\mathrm{t}]$ he war of attempted secession has, of course, been the distinguishing event of my time"; Prose Works 1892, ed. Floyd Stovall (New York: New York University Press, 1963-1964), 1:2 (hereafter PW). And in "A Backward Glance O'er Travel'd Roads," Whitman suggested that the war, "a sudden, vast, terrible, direct and indirect stimulus for new and national declamatory expression" enabled him to realize his poetic ideals: "It is certain, I say, that, although I had made a start before, only from the occurrence of the Secession War, and what it show'd me as by flashes of lightning, with the emotional depths it sounded and arous'd (of course, I don't mean in my own heart only, I saw it just as plainly in others, in millions) - that only from the strong flare and provocation of the war's sights and scenes the final reasons-for-being of an autochthonic and passionate song definitely came forth"; Leaves of Grass, Comprehensive Reader's Edition, ed. Harold W. Blodgett and Sculley Bradley (New York: New York University Press, 1965), 569-570 (hereafter LG).

2 Memoranda During the War (1875) was included with only slight modifications in Specimen Days (1882). Peter Coviello notes that "[1] arge portions of the book first appeared in a series of newspaper articles that Whitman published about the war in 1874, called "Tis But Ten Years Since"'; Memoranda During the War, ed. Peter Coviello (New York: Oxford University Press, 2004), xv-xvi.

3 Whitman went to Washington in 1862 in search of his brother, whom he feared was wounded. Before he found his brother, who was only grazed by a shell in the cheek, Whitman wanders through numerous hospitals in Washington D.C. and sees the often commented-upon cart full of amputated limbs near Fredericksburg. See Gay Wilson Allen, The Solitary Singer: A Critical Biography of Walt Whitman (New York: New York University Press, 1969), 281-283. 
4 In contrast, Herman Melville in Battle-Pieces seemed quite content to bury the war. In the "Supplement" to Battle-Pieces Melville wrote, "It is enough, for all practical purposes, if the South have been taught by the terrors of civil war to feel that Secession, like Slavery, is against Destiny; that both now lie buried in one grave"; Battle-Pieces and Aspects of the War (New York: Da Capo Press, 1995), 260.

5 Oxford English Dictionary, Oxford University Press; available online at www.oed.com (hereafter $O E D$ ).

6 Both Melville and Whitman also likened the Civil War to the geological convulsiveness of a volcano or an earthquake. Whitman notes that the Civil War is "like an earthquake" (PW, 1:25) and Melville's poem "The Apparition (A Retrospect)" likened the war to the unpredictability and sudden violence of a volcano (155).

7 Timothy Sweet, Traces of War: Poetry, Photography, and the Crisis of the Union (Baltimore: Johns Hopkins University Press, 1990), 16, quoting Cronick.

8 Walt Whitman, Leaves of Grass: A Textual Variorum of the Printed Poems, ed. Sculley Bradley, Harold W. Blodgett, Arthur Golden, William White (New York: New York University Press, 1980), 1:31. Hereafter abbreviated LG Var.

9 Whitman also described these writings as a product of "the convulsive memories" of his war experiences ( $P W, 1: 321)$.

10 M. Wynn Thomas, "Weathering the Storm: Whitman and the Civil War," Walt Whitman Quarterly Review 15 (Fall 1997/Winter 1998), 97.

11 Mark Maslan, Whitman Possessed: Poetry, Sexuality, and Popular Authority (Baltimore: Johns Hopkins University Press, 2001), 88.

12 In Memoranda Whitman noted, "In February '73 I was stricken down by paralysis" (PW, 1:118). In the "Prefatory Letter of the Readers" of the 1889 edition of Leaves of Grass Whitman describes his current health problems as "bequests of the serious paralysis at Washington, D.C., closing the Secession War-that seizure indeed the culmination of much that preceded, and real source of all my woes since" (LG, 561). Also see Harold Aspiz, Walt Whitman and the Body Beautiful (Urbana: University of Illinois Press, 1980), 25-27.

13 Katherine Kinney, "Making Capital: War, Labor, and Whitman in Washington, D.C.," Breaking Bounds: Whitman and American Cultural Studies, ed. Betsy Erkkila and Jay Grossman (New York: Oxford University Press, 1996), 174.

14 Betsy Erkkila, Whitman the Political Poet (New York: Oxford University Press, 1989), 196.

15 M. Wynn Thomas, "Fratricide and Brotherly Love: Whitman and the Civil War," The Cambridge Companion to Walt Whitman, ed. Ezra Greenspan (Cambridge: Cambridge University Press, 1995), 35-36.

16 Gregory Eiselein suggests that "The Wound-Dresser" shows Whitman reaching the limit of his ability to imaginatively project himself into the experience of the wounded. He argues that the radical identification and transposition in "Song of Myself" is no longer possible for Whitman; Literature and Humanitarian Reform in the Civil War Era (Bloomington: Indiana University Press, 1996), 104-105.

17 Interestingly this role of nurse is very similar to what we see Whitman doing for the runaway slave in "Walt Whitman." The poet "brought water, and filled a tub for 
his sweated body and bruised feet, / . . / He staid with me a week before he was recuperated and pass'd north" (LG Var., 1:12).

18 Erkkila notes that Whitman did, in fact, make a great many changes in publishing his diaries and notebooks (208). Sweet feels that the presence of the blood-stains "prevents Whitman from representing them; their reality thwarts textualization" (48). I see this as a minor matter when compared to the other difficulties that Whitman faced in representing the war.

19 Regarding this see Michael Fried's analysis of the thematization of writing in Eakins and Crane; Realism, Writing, Disfiguration: on Thomas Eakins and Stephen Crane (Chicago: University of Chicago Press, 1987).

20 The passage from "Calamus" 15 in which writing is thematized as bleeding is:

O drops of me! trickle, slow drops,

Candid, from me falling, drip, bleeding drops,

From wounds made to free you whence you were prisoned,

$\cdots$

Stain every page, stain every song I sing, every word I say, bloody drops,

Let them know your scarlet heat, let them glisten,

Saturate them with yourself all ashamed and wet... (LG Var., 2:385).

21 A fascicule is a leaf, but these are quite different than those in Leaves of Grass $(O E D)$.

\section{$22 O E D$.}

23 Thomas, "Fratricide and Brotherly Love," 43.

24 Robert Leigh Davis, Whitman and the Romance of Medicine (Berkeley: University of California Press, 1997), 8.

25 For instance, Whitman in Democratic Vistas does write, "As circulation to air, so is agitation and a plentiful degree of speculative license to political and moral sanity" $(P W, 2: 383)$. But this is only a metaphor.

26 Coviello, Memoranda, xli-xlii.

27 Elaine Scarry, The Body in Pain: the Making and Unmaking of the World (New York: Oxford University Press, 1985), 5.

28 Whitman even contacted Redpath, Alcott's publisher for Hospital Sketches, and tried to interest him in Memoranda. Ultimately, Whitman published this book at his own expense, an indication that he felt his book needed to be read and shared.

29 Louisa May Alcott, Hospital Sketches (Cambridge: Harvard University Press, 1960), 44.

30 Maslan himself seems to note the sacrificial character of some of these exchanges. For instance, regarding "A March in the Ranks Hard-Prest," he argues that "the lad's death is quite literally Whitman's inspiration: just as he seems to absorb the blood he stanches, so he appears to internalize the spirit whose departure from the lad the blood signals" (123).

31 “Our Army at Washington," Harper's Weekly (June 1, 1861).

32 Donald E. Pease, Visionary Compacts: American Renaissance Writings in Cultural Context (Madison: University of Wisconsin Press, 1987). 
33 Mark Seltzer, Bodies and Machines (New York: Routledge, 1992), 3.

34 After returning home the artillery man relives the war in dream: "this vision presses upon me; / The engagement opens there and then in fantasy unreal, / The skirmishers begin, they crawl cautiously ahead, I hear the irregular snap! snap!” (317).

35 As I've already argued, I don't think the fact that the wounded are marked by technology is well-hidden at all.

36 Mary Clemmer, Ten Years in Washington: Life and Scenes in the National Capital As a Woman Sees Them (Cincinnati: Queen City Publishing, 1874), 476.

37 Walter Benn Michaels discusses Weir Mitchell's bizarre 1866 story, "The Case of George Dedlow." In this uncanny tale a young doctor fights in the Civil War and loses both arms and legs. During a séance a spirit tells him that his legs are in the "UNITED STATES ARMY MEDICAL MUSEUM, Nos. 3486, 3487"; Walter Benn Michaels, The Gold Standard and the Logic of Naturalism: American Literature at the Turn of the Century (Berkeley: University of California Press, 1987), 24. During the séance his legs are temporarily spiritually returned to him and he hobbles around for a few minutes. This re-membering of war in which the body is turned into freakish spectacle and gazed on with curiosity does not seem to be what Whitman has in mind.

38 Scarry notes that "whether or not it is verbally memorialized, the record of war survives in the bodies, both alive and buried of the people who were hurt there" (113).

39 Bill Brown, The Material Unconscious: American Amusement, Stephen Crane, E the Economies of Play (Cambridge: Harvard University Press, 1996), 202.

40 Alan Trachtenberg, "Albums of War: On Reading Civil War Photographs," Representations 9 (1985), 6 .

41 Sweet and others note that, while Brady took very few photographs of the war, he played an important role in commissioning photographers, buying their work, and reissuing these photographs in a variety of formats.

42 This is the title of his 1995 article. Mark Seltzer, "Serial Killers, II: The Pathological Public Sphere," Critical Inquiry 22 (1995).

43 Gregory Eiselein argues that Whitman in Sequel to Drum-Taps offers an eccentric model of mourning. While Whitman links grief to seasonal and cyclical time, he presents mourning as a non-normative and non-linear process, in contrast to most contemporaneous representations of grief. Eiselein shows how for Whitman sadness and grief return intermittently. I would describe these periodic returns as convulsions.

44 Sally Pierce, Temple D. Smith, and Boston Athenaeum, Citizens in Conflict: Prints and Photographs of the American Civil War (Boston: Boston Athenaeum, 1981), 34.

45 Image included in Alexander Gardner, Gardner's Photographic Sketch Book of the Civil War (New York: Dover Publications, 1959), plate 36.

46 Quoted in Horace Traubel, With Walt Whitman in Camden (Boston: Small, Maynard, 1906), 1:115.

47 Thomas, "Weathering the Storm," 103.

48 Cathy Caruth, Trauma: Explorations in Memory (Baltimore: Johns Hopkins University Press, 1995), 5. 